\title{
The Place of Hebrew: Maya Arad's Another Place, a Foreign City
}

In 1995, the Israeli writer Maya Arad was completing a Ph.D. in Linguistics at University College London, when she picked up a copy of The Golden Gate, the debut novel of the Indian author Vikram Seth. Published in 1986, Seth's novel about academic life in the San Francisco Bay Area consisted entirely of Pushkin sonnets, a variation on the sonnet form developed by the nineteenth century Russian poet Aleksandr Pushkin for his narrative poem Yevgeny Onegin (Seth 1986). Seth's novel inspired Arad to revisit Pushkin's Onegin in the Russian original, and it was this rereading that prompted Arad to take a closer look at Avraham Shlonsky's highly lauded 1937 Hebrew translation of Onegin (Shlonsky 1937), which she has described as, "the best translation ever written for the most perfect masterpiece of world literature" (Arad 2008). ${ }^{1}$ These three texts - Pushkin's Russian classic, Shlonsky's Hebrew translation and Seth's contemporary English-language novel - persuaded Arad to write a Hebrew novel-in-verse on contemporary Israeli identity from an expatriate perspective. By the time she completed the first draft of her novel, Arad herself was living in California, where she has been a writer-in-residence at Stanford University for many years - and also where Seth had resided during the writing of The Golden Gate. Published in 2003, Arad's Makom acher ve-'ir zara (Another Place, a Foreign City) was an immediate bestseller in Israel, where it won numerous literary prizes and was later made into a stage musical that ran at the Cameri Theater in Tel Aviv for a year, starring the Palestinian Israeli actress Mira Awad.

In the Israeli press, appraisals of Another Place, a Foreign City focused on its linguistic virtuosity and its complex portrayal of Israeli identity vis-à-vis immigration (Lev-Ari 2005; Melamed 2003; Melcer 2003). Describing the novel's rich language, Liam Azoulay-Yagev wrote, "for lovers of Hebrew, this rhyming book is the equivalent of a mound of ice cream with syrup, whipped cream, and a cherry on top" (Azoulay-Yagev 2004). In fact, the writer and linguistic Ruvik Rosenthal was even moved to compose his own review in Pushkin sonnets (Rosenthal 2004). In addition to the themes of identity that Arad explores, the novel also brought together her interests in translation, intertextuality, classic poetic forms, and the continued influence of the Russian literary tradition on

1 All translations from the Hebrew are mine unless otherwise noted.

Ә OpenAccess. () 2020 Adriana X. Jacobs, published by De Gruyter. (cc) BY-NC-ND This work is licensed under the Creative Commons Attribution-NonCommercial-NoDerivatives 4.0 License. 
modern Hebrew writing. ${ }^{2}$ The Israeli scholar Aminadav Dyckman, in a blurb on the book's back cover, observed that by using a Russian text as her inspiration, Arad had created a framework for writing that allowed her to explore Israeli identity and belonging in new, and, in his word, "refreshing," ways (Arad 2003).

Arad herself left Israel in 1994, a year after the signing of the Oslo I Accord, and as a Hebrew writer who no longer lives in Israel, her work has entered discussions on the future coordinates of Israeli literature and the status of Hebrew diasporic literature in Israel. As Yaron Peleg notes, the fact that contemporary Hebrew diasporic writing exists is not on the face of it remarkable, indeed, as he puts it, "the concentration of Hebrew in one geographic location is a relatively recent phenomenon” (Peleg 2015, 323). Nonetheless, he argues that writers like Arad create works "written outside of Israel only in relationship to the sovereign Hebrew state" (Peleg 2015, 324) and discerns in such works an "ambivalent" expression of the author's own immigration. Rachel Harris, on the other hand, sees a different trend at work, one that reflects the increasingly "transcultural identity" of Israeli literature represented by writers who, in her words, "are comfortable exploring other cultures and other places, while simultaneously re-exploring their homeland and notions of home" (Harris 2015, 3). In his work on Hebrew writing in the United States, Michael Weingrad also considers how writing in the digital age problematizes characterizations of this literature as diasporic and transnational. Citing Arad's visibility and success in the Israeli literary market, Weingrad argues that "technology and new media make separate, geographically identified linguistic subcultures less distinct if they exist at all" (Weingrad 2015, 295). As a work composed in the United Kingdom and the United States, Arad's novel calls attention to the transnational routes by which Hebrew literary texts may continue to circulate in the twenty-first century, but as a Hebrew writer in the United States who writes for a readership that resides primarily in Israel, Arad's work is also, as Weingrad describes it, "an extension of Israeli literature" (Weingrad 2015, 295). ${ }^{3}$ Indeed, how far Israeli literature may extend has been a point of contention in Israeli cultural discourse, touching on anxieties concerning the relation between territory and language in formulations of contemporary Israeli literature, anxieties that Arad's novel addresses. ${ }^{4}$

2 Since its debut issue, Arad has been affiliated with the journal Ho! which positioned itself at the forefront of a neoformalist turn in early twenty-first century Hebrew writing. For a discussion on contemporary Hebrew neoformalism, see Jacobs (2017).

3 See Pinsker (2010) and Shachter (2011) for rich discussions on the transnational routes of Hebrew and Yiddish literatures in the nineteenth and early twentieth centuries.

4 The latter became a point of contention when Ruby Namdar, who lives in New York City, won the prestigious Sapir Prize in 2014 for his novel Ha-bayit asher nechrav (The Ruined House), the 
The backdrop of Arad's novel is Tel Aviv in the early 1990s, when the dissolution of the Soviet Union precipitated a major wave of immigration to Israeli, resulting in radical and rapid demographic shifts in Israeli society. In the first section or canto of the novel, we are introduced to its protagonists, Orit and Jason "Jay" Rifkin. Orit is less than a year away from completing her military service, and in addition to writing a manual on Israeli identity, she has been asked to mentor Jay, a recent immigrant from Canada. Jay is fulfilling his army service in the Education Corps - the division in which Arad completed her own army service - and when the novel opens, he is still struggling with his Hebrew language skills. Orit is captivated by, and even infatuated with, the new immigrant. Jay, on the other hand, appreciates the access to Israeli culture that Orit's presence in his life provides, but, for the most part, remains oblivious to her desire for a romantic connection. When the novel's narrator turns her attention to Jay, he's often sitting alone in a cafe or wandering aimlessly through Tel Aviv (Arad 2003, 34). “To improve his language skills” he reads Hebrew literature or peruses Israeli newspapers, but most of his every day interactions with Israelis can be summarized by the occasional "shalom" that he exchanges with his neighbors (Arad 2003, 40).

Jay's - and Orit's - anxious and ambivalent sense of belonging intensifies in a pivotal episode in Canto III, when Orit invites Jay to join her on a short excursion to Jerusalem, where she has arranged an interview with Professor Yehuda Haim Ets, a venerated Israeli scholar of international repute. Jay instantly recognizes the name - he recalls that he attended a lecture the Professor gave on "Theology and the Holocaust" in Toronto. Ets was born somewhere in Europe before World War II but intentionally keeps the details of his biography as a "riddle" for his supporters and detractors to solve (Arad 2003, 49). Regardless, the peripatetic Ets, who divides his time between academic posts in Geneva, Germany, Los Angeles and Jerusalem, is considered a major ambassador of Israeli scholarship abroad. He is bemused and fascinated by Orit's question "What is Israeli Identity?" and in a response that spans several sonnets (Arad 2003, $60-65$ ), Ets meditates on the distinction between cultural and religious Judaism and how it has shaped Israel-Diaspora relations, but to Orit's exasperation, he refuses to give her question a straight answer and is openly troubled by her insistence on a separation between cultural and religious Judaism. In Sonnet \#31, he offers a passionate assessment of the legacy of biblical Hebrew and the debt that modern Hebrew literature owes to it:

first time the award went to an expatriate writer. Due to the subsequent backlash, the prize guidelines now stipulate that residency in Israel is required. 
"What is our literature (sifrutenu) worth

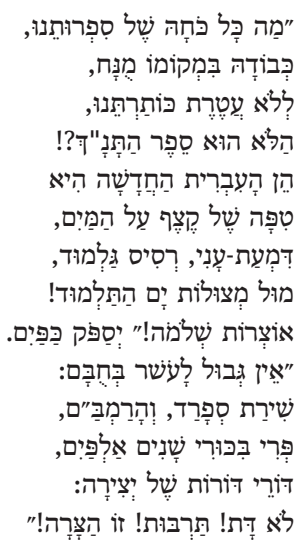
in the end, with all due respect, without its crowning jewel: the Bible, the crème de la crème? In truth modern Hebrew is but a poor tear, a solitary fragment, a bit of foam on the surface of the Talmud's ocean depths! King Solomon's treasure!” He cheers.

"A wealth of debt: Maimonides, the poetry of Andalus, the fruits of two thousand years, generations of creative acclaim: Not religion! Culture, you say! Shame!” (Arad 2003, 63)

Ets defends the place of religion in cultural Judaism and, by tying it to Hebrew literature, in Israeli culture as well, but his characterization of modern Hebrew literature as "a solitary fragment" vis-à-vis the Hebrew Bible invokes the continuum model of Hebrew literary history. References to the Talmud and the poetry of al-Andalus recall the long diasporic history of Hebrew literature, but his characterization of Hebrew literature as "sifrutenu" - our literature - is notable here. In his work on Jewish literature, Dan Miron has addressed the psychological valence this term carried in the pre-Statehood period where it "conveyed a sense of intimacy, of belonging" that later became outmoded, replaced by an interest in Hebrew literature as both a "general literature" and a national one (Miron 2010, 10 -11). Ets's understanding of "sifrutenu" is also explicitly monolingual; what is conspicuously missing here is Hebrew literature's longstanding, dynamic relation to other languages, like Yiddish and Arabic.

It is during this interview with the great scholar that Jay, who until then had been struggling with his Hebrew, finds his voice. Arad captures the moment 
when Jay summons the will to speak in highly charged, dramatic language. The right words literally "rise from the deep," breaking from the restraints of Jay's limited and insecure vocabulary (Arad 2003, 66). What makes this moment remarkable is that throughout the novel Jay's language constantly marks him as a non-native Hebrew speaker. Often, he'll slip into English, particularly when he is overcome with emotion, but also when he calls his family, conversations that appear in the novel in English. In an early scene, Orit even traces his initials, $J$. R., with Roman letters, on the misted glass of her bedroom window (Arad 2003, 44). Arad renders these moments without disrupting the prosody of the Hebrew text. Hebrew finds a way of accommodating English, of working with it to keep the conventions of the Pushkin sonnet intact. But it isn't English alone that marks Jay as a new immigrant. His Hebrew also contains "ketsat mivta," a slight accent, which even years later Jay is unable to shake off (Arad 2003, 42).

When Jay finishes his speech - a passionate proclamation that Israel-Diaspora relations can be reconciled only through immigration - Ets turns to Orit and asks her where she is from. To which Orit indignantly replies "Me? From here! From Israel!” Without skipping a beat, Ets confesses that he had assumed Orit was the immigrant (Arad 2003, 67). The irony is not lost on Orit - that she has been assigned the role of native informant to acclimate Jay to native Israeli culture. And yet, it is she, the "sabra," as Ets calls her, who is struggling to complete her manual on Israeli identity. (Later, we learn that Orit has completed a highly praised guide on Israeli identity though the narrator never reveals its contents.) Throughout the novel, it is Orit, even more so than Jay, who feels restless, unsettled, grappling with the feeling of not feeling quite at home. Jay, who was raised in Montréal, has been part of a religious and cultural minority most of his life. Indeed, the fact that he speaks English with his parents and not French is consistent with his affiliation with Montréal's primarily Anglophone Jewish community. For Jay, living in Israel allows him to be part of a majority culture for the first time. His attempts to acquire the trappings of Israeliness - the Hebrew language, army service - give him a sense of footing and purpose in Israel. However, Orit's slippery hold on her own Israeliness suggests that the relation between territory, language and identity has been destabilized, precisely when Jay is most relying on its durability. For Orit, Jay's presence in her life brings a different horizon into view, the possibility of a life in a "makom acher."

Canto I of Makom acher ve-ir zarah opens with an epigraph from A.B. Yehoshua's 1989 book of essays Ha-kir ve-ha-har (The Wall and the Mountain): "The typology of Hebrew literature has become slightly monotonous in its maturity [...] perhaps one could attempt to expand this typology through Jewish ideas from outside of Israel” (Yehoshua 1989, 98; Arad 2003, 7). Arad's turn towards older, canonical texts allows her to interweave a wide range of literary texts 
from various languages, cultures and historical periods. In so doing, Arad expands the perceived borders of Israeli writing to let new and different voices bear on familiar and long-standing debates and questions concerning Israeli identity, reflecting on the recent past of the twentieth century from the vantage point of the twenty-first. The very language of Arad's novel explores the continued presence of "outside ideas" on late twentieth century Israeli writing in Hebrew though she does not restrict her sources to Jewish ideas, as Yehoshua recommends. In fact, by using Pushkin's Onegin as a framework for a novel set in Israel, which she began in London and finished in Stanford, Arad advances the possibility of "narrating the nation," in Homi Bhabha's words (Bhabha 1990, 1), within or through non-Israeli, and even non-Jewish, frameworks. But at the same time, through her rereading and citation of Shlonsky's translation, Arad calls attention to the ways in which Hebrew writers throughout the twentieth century have explored, and even contested, the Israeli "inside." In this respect, Arad positions her own writing as both a continuation and an intervention.

On the one hand, globalization has resulted in cultural, linguistic and national affiliations that are increasingly shifting and in flux, but on the other, the technologies of communication and commerce that shape global communities have also allowed authors to continue to work and participate remotely within national frames. Teaching and discussing this novel in the United States and in the United Kingdom affords an opportunity to consider these concerns in contexts where the relation between nation and language is also highly contested and to contemplate what happens when we bring Arad into the orbit of "literature in the United States" and "Jewish American literature." But these moves often require that I rely on my own partial and selective English translation (Jacobs 2007), which introduces the additional complication of translation into English, the dominant language of the global literary market. ${ }^{5}$ Translation can radically reconfigure literary canons by introducing, but also making visible, what Johannes Göransson terms the "transgressive circulation" of texts and authors (Göransson 2018), while running the risk-particularly in the case of Anglophone translation-of reinforcing hegemonic monolingualism. At the same time, teaching Arad in English translation brings her work into relation with what Melissa Weininger terms "Hebrew literature in English." Written in English by Israeli

5 Arad's novels have not appeared in full English translations, though excerpts from Oman hasipur ha-katsar (2009, Master of the Short Story) and Ha-'alma mi-kazan (2015, Our Lady of Kazan), both translated by Jessica Cohen, are available in print issues of World Literature Today and Paper Brigade respectively. Cohen's translation of the short story "Omsk" is available online: https://www.jewishfiction.net/index.php/publisher/articleview/frmArticleID/244 (1 June 2020). 
writers, these works, Weininger argues, "reverse the process of territorialization Hebrew underwent through the establishment of the State of Israel by deconstructing the relationship between language and nation, and nation and place” (Weininger 2015, 18). In these works, English may be the primary language of these texts, but Hebrew is nonetheless "inflected" throughout (Weininger 2015, 22). Such inflections are present in Arad's novel as well, not only in its references to Jay's accented Hebrew, but also in the very language of the novel-a Hebrew drawn from a Russian text (Pushkin) and its various translations and reworkings in Hebrew (Shlonsky) and English (Seth).

In a conversation that Arad and I conducted in the pages of Sh'ma, A Journal of Jewish Responsibility, I asked her to reflect on the relevance and importance of translators and translation, and the prominent place both occupy in her work, which prompted the following, personal reflection:

\footnotetext{
Why this emphasis? We care about translation because we care about history. We need translation because we need the ironic distance it provides. Israeli culture tends to be too "literal," too "direct," and too obsessed with its own present state of being. It was against this background that my generation rebelled. You are right that my work addresses identity - Israeli, Jewish; these are my themes. But bear in mind the irony in all of that, the sense that there is also something faintly absurd in all those Israeli obsessions. Identities are always clichés (they are, after all, what is supposed to make things identical)...I am distant from Israel, in several ways. (Arad and Jacobs 2010, 13)
}

Translation and identity (or a resistance to defining it) go hand in hand for Arad. In its broadest formulation, translation is about bringing that which is distant closer - a work in a language someone doesn't know is made accessible through translation - but for Arad it also provides in her words "an ironic distance" that her work retransmits into the Israeli local.

By creating a literary text that so explicitly engages translation, multilingualism, and intertextuality, Arad acknowledges the heterogeneity of Israeli literature, the continued presence of "outside ideas" and marginalized "inside ideas" at work in Israeli culture, and the transnational and diasporic future of Hebrew literature. To the extent that Arad's work addresses these questions, it also interrogates the very notion of a "national canon" in a world where authors and texts circulate in - and are translated into - increasingly global and transnational networks. Indeed, in the second sonnet of Canto Eight, her narrator proclaims "lo tov heyot adam cavul," It is not good for a man to be tied down - a line that echoes Genesis 2:18, "lo tov heyot ha-adam levado," It is not good for 
the man to be alone (Arad 2003, 167). ${ }^{6}$ In Makom acher, ve-ir zara, Orit ultimately abandons her romantic attachment to Jay, but Arad's radical revision of the biblical text foreshadows the other ties from which she'll disengage.

Several years later, Orit and Jay run into each other in Tel Aviv, an event that Arad's narrator relates in Canto 8, the final canto of the novel. Jay is now 34 and pursuing a course of study at the Hebrew University under the supervision of Professor Ets. He is proud to show Orit that in Ets's most recent book he is acknowledged for his translation assistance. Still single and, despite his long stay in Israel, restless, Jay now he sees Orit in a different light, as a missed opportunity to feel more settled in his new home. He wonders if there is a chance still for the two of them, but Orit is disillusioned by the encounter. The narrator remarks, alluding to Numbers 13:32, "in his youth he greedily ate up the land- / and now she eats him up" (Arad 2003, 172). All that remains of the young man she once loved is "oto mivta, oto chiyukh," the same accent, the same smile (Arad 2003, 176). When he offers to stay in touch, she informs him that she lives "somewhat far away," in Vancouver. Jay receives this news with surprise because there is nothing about Orit that suggests that she no longer lives in Israel.

On the flight back to Vancouver, Orit is roused by the morning light - and for a moment, in that state between sleep and waking, she is somewhere between Vancouver's sunrise and Tel Aviv's sunset:

She immediately falls to her right

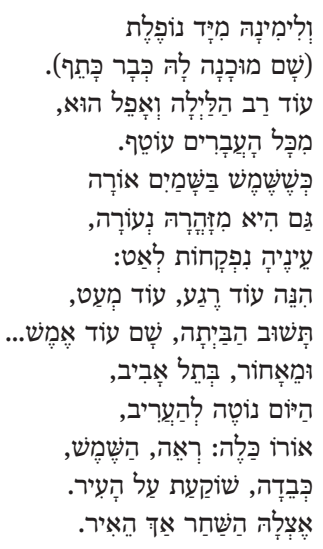

(a ready shoulder awaits her there)

another long and dark night

envelopes her from all sides.

6 This line from Genesis 2 also appears in a poem by Natan Zach that has been set to music and performed by a number of notable Israeli musicians including Matti Caspi and Yehudit Ravitz. 


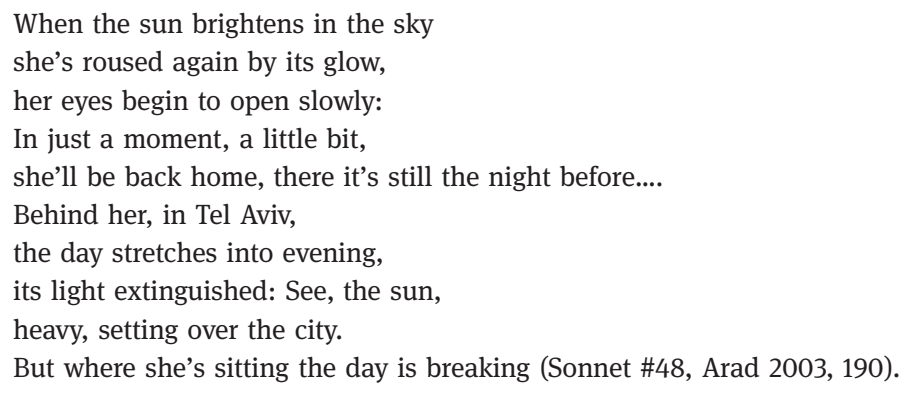

This parting image of Orit suspended mentally between the two cities recalls Leah Goldberg's 1955 poem "Oren” (Pine), which contains the iconic lines "ulai tsiporei masa yodot/ke-she-hen tluyot beyn erets ve-shamayim/et ze ha ke'ev shel shtei ha-moladot" (Goldberg 173, 143). Perhaps traveling birds know/ as they hover between earth and sky/ this pain of the two homelands. Arad's closing scene suggests, as in Goldberg's poem, the possibility of being in two places at once, in a state of translation. "I am there, in Israel," writes Arad, "but not quite" (Arad and Jacobs 2010,13). And as Orit crosses the horizon, for a moment, it's almost like she has never left.

\section{Bibliography}

Arad, Maya. Makom acher ve-'ir zara [Another Place, a Foreign City]. Tel Aviv: Xargol Books, 2003.

Arad, Maya. “Hine kakh hu ha-mefuzar: Masa ‘al 'Ha-mefuzar mi-kfar azar” ve-'al mekoro ha-rusi” [On “The Scatterbrain from the Village Azar” and its Russian Source]. Ho! 1 (January 2005): 145-160.

Arad, Maya. "Ve-kan ha-pele ha-gadol” [And here, the great wonder]. Haaretz (7 January 2008). https://www.haaretz.co.il/literature/poetry/1.1299327 (1 June 2020).

Arad, Maya and Jacobs, Adriana X. "Another Voice: Letters on the Art of Translation." Sh'ma: A Journal of Jewish Responsibility (December 2010): 12-13.

Azoulay-Yagev, Liam. “Kulam sho’alim ma ze sabudi/ beyn ha-tohim gam Balsar Dudi.” Nana (5 January 2004).

Bhabha, Homi K. “Introduction.” Nation and Narration. Ed. Homi K. Bhabha. London: Routledge, 1990.

Goldberg, Leah. Shirim (Poems), vol. 2. Ed. Tuvia Ruebner. Tel Aviv: Sifriyat po‘alim, 1973.

Göransson, Johannes. Transgressive Circulation: Essays on Translation. Blacksburg, VA: Noemi Press, 2018.

Harris, Rachel S. "Israeli Literature in the $21^{\text {St }}$ Century: The Transcultural Generation: An Introduction.” Shofar 33.4 (2015): 1-14. 
Jacobs, Adriana X. "Another Place, a Foreign City - An Excerpt.” Zeek: A Jewish Journal of Thought and Culture (December 2007): http://www.zeek.net/712fiction/ (20 November 2019).

Jacobs, Adriana X. "Ho! and the Transnational Turn in Contemporary Israeli Poetry." Prooftexts 36.1-2 (2017): 137-166.

Lev-Ari, Shiri. “A View from Abroad.” Haaretz (22 September 2005). https://www.haaretz. com/israel-news/culture/1.4875285/ (1 June 2020).

Melamed, Ariana. "Zan nadir" [A Rare Species]. Ynet.co.il (11 November 2003). https://www. ynet.co.il/articles/1,7340,L-2812746,00.html (1 June 2020).

Melcer, loram. "Mifgash mi-sug acher" [A Different Kind of Encounter]. NRG Maariv (11 December 2003). https://www.makorrishon.co.il/nrg/online/archive/ART/606/107.html (1 June 2020).

Miron, Dan. From Continuity to Contiguity: Toward a New Jewish Literary Thinking. Redwoods City, CA: Stanford University Press, 2010.

Peleg, Yaron. “A New Hebrew Literary Diaspora? Israeli Literature Abroad.” Studia Judaica 18.2 (2015): 321-338.

Pinsker, Shachar. Literary Passports: The Making of Modernist Hebrew Fiction in Europe. Redwoods City, CA: Stanford University Press, 2010.

Rosenthal, Ruvik. "Sod ha-nikayon" [The Secret of Cleaning]. NRG Maariv (13 February 2004). https://www.makorrishon.co.il/nrg/online/archive/ART/647/726.html (1 June 2020).

Schachter, Allison. Diasporic Modernisms: Hebrew and Yiddish Literature in the Twentieth Century. Oxford: Oxford University Press, 2011.

Seth, Vikram. The Golden Gate: A Novel in Verse. New York: Random House, 1986.

Shlonsky, Avraham. trans. Yevgeny Onigin (roman be-charuzim) [Evgeny Onegin: A Novel in Verse] by Aleksandr Pushkin. Tel Aviv: Va'ad Ha-yovel, 1937.

Weingrad, Michael. "Hebrew in America." The Cambridge History of Jewish American Literature. Ed. Hana Wirth-Nesher. Cambridge: Cambridge University Press, 2015. 281-296.

Weininger, Melissa. "Hebrew in English: The New Transnational Hebrew Literature." Shofar 33.4 (2015): $15-35$.

Yehoshua, A. B. “Likhtov proza: reya'on" [Writing Prose: An Interview]. Ha-kir ve-ha-har [The Wall and the Mountain]. Tel Aviv: Zmora-Bitan, 1989. 